\title{
The Influence of Spatial Transformation on the Economic Growth of Aceh - Indonesia: A Spatial Econometric Model
}

\author{
Maimun ${ }^{1}$, Abubakar Hamzah ${ }^{2}$, Mohd.Nur Syechalad ${ }^{3}$, Nazamuddin ${ }^{4}$ \\ 1,2,3,4Doctor of Economic Sciences,Syiah Kuala University, Banda Aceh, Indonesia \\ 1,4Coresponding author : maimun.ma@yahoo.com; nazambs@yahoo.com
}

\begin{abstract}
In the last decade, counties of Aceh Province was transformed into twenty three counties from ten. This tranformation implies to differencing on economic growth these counties between before and after transformation. finding out the conditional convergence economic growth when spatial effect is included. This research is developing in spatial econometrics study. This research is using descriptive statistical analysis; continue with Spatial Durbin Model (SDM) approach which is show significance pattern of the perfomance interpendence. Exploratory Spatial Data Analysis (ESDA) by using Statistical Analysis System (SAS) and Minitab Software. Generally, our results suggests conditional convergence economic growth after transformation among counties in Aceh when spatial effect is included.
\end{abstract}

Keywords: Growth, Conditional Convergence, Spatial Durbin Model

\section{Introduction}

Regional economic development paradigm, which is taking place in developed countries and developing countries will continue to experience a variety of developments in line with advances in technology and the ever changing economic structure. With the development, population and economic activity will pick the location of activities adjacent to urban areas and a variety of other areas, which is close to the location of the local market (domestic), nationally and internationally. The concentration of the location of economic activity has become a fact of life that lead to economic growth will continue to experience growth over time.

Economic activities usually concentrated in big city for each country. Tokyo city claimed that only 4 percent land from total geographic of Japan lived by 25 percent population. Gross National Product (GDP) of Egypt moreover 50 percent concentrated in Cairo city as capital city. Whereas, Cairo's land less than a half percent from total Egypt land. North America, Europe and Japan whose population less than one billion have 2/3 product of all around the world. More than 50\% of GDP of Indonesia is result from the usage only 5\% from total land (World Bank, 2009). Studies of Word Bank show economic growth each country implies spatial polarization and resources allocation (capital investment) concern to competitive and rich region/city. There are many concepts of convergence, Europe Commission (2006) in Sardadvar (2011) defines convergence as a process wherebly the lesser developed regions approach mean gross domestic product of the european Union. Quah (1993) define convergence as each country eventually becomes as rich as all the others-the cross section dispersion diminishes over time.

The common definition by Sala-i-Martin (1996) that convergence is defined as $\sigma$-convergence which is observed if the variance of income declines to zero over time and $\beta$-convergence which relies the speed of convergence and is related to $\sigma$-convergence, as it constitute a necessary but not sufficient condition for $\sigma$-convergence to occur. $\beta$-convergence is for overtaking wich may lead to an increasing variance, while $\sigma$-convergence works if variance declines. $\beta$-convergence is for knowing influence factors to speed level of convergence. Two steps procedure of $\beta$-convergence are starting by find out the existance of absolute convergence and next step is test significancy of explained convergence or conditional convergence. Absolute convergence is defined as a testing hypothesis that poor economies (regions) tend to grow faster per capita than rich ones without conditioning on any characteristics of economies (regions). In the other hand, conditional convergence is defined as forheterogeneity across economies (regions) and testing the hypothesis that an economy grows faster the further it is from its own steady state (Sardadvar,2011). It is identicaly to Barro and Martin (2004) that convergence consisted into two type, absolute and conditional convergence. Negatif of $\beta$ implies there is negative correlation between income percapita level during $\mathrm{T}$ periods with initial income. In the other word, theres is increasing income during this periods.

Spatial polarization and resources allocation have the impact to convergence of economic growth. Nevertheless, in the early may occur random or divergence overtaking to convergence economic activities. When enhance of income per capita and living standart arise, it may concentrated either in mass economic or the other not mass economic region. Its need hypothesized and tested to know economic growth concentrated or not.In a developing region, the fastness of migration people and economic activities usually diverse concentrated. Depend on level of spatial of economic resources works (World Bank, 2009). In the other word, economic growth a region do not usually depend on income, savings, human capital and technologies. But be able depend on interdependence of influence neighborhood/spatial spillover effect (Sardadvar, 2011 and Tian, Wang and Chen, 2010). There are two 
type pattern of Spatial spillover effect of Economic growth, spread random and clusterpattern. Random patternindicate regions have no interdependence each other. In the other way, cluster pattern indicate any interdependence between region/location. Spatial autocorrelation is indicate the value relationship of location. The influnce of location to another devided into two spatial value, positive for completely separated pattern and negative for evenly space pattern/random pattern (Anselin, 2005). Positive spatial indicate location with have same characteristic grouped into same space. Negative spatial indicate a locations is surrounded by another location with different characteristics. Moran's I Statistic and Moran Scatterpplot diagram is value and patten ofspatial autocorrelation to measure the influence spatial effect between location in the different time (Anselin, 2005).

This paper attempt to find existance of conditional convergence of economic growth among Aceh province after regional expansion during 2001-2010 period when spatial lag effect is included. It has a hypothesis whether there is a county's economic growth in Aceh province is influenced by sorrounding counties. In the period 2001-2010 counties in Aceh province transformed into 23 counties from ten ones. It is attract research which to know whethe there is affect of regional expansion will bring convergence of wellfare to new counties. In the other word the policy of regional expansion is successful when there is positve economic growth. Significant of lag spatial $\rho$ implies that a county's economic growth depended by not only own resurces but also by another neighbour counties.

\section{Problem Formulation}

1) Is there any statistically difference, before and after spatial transformation of counties to economic growth in Aceh province?

2) Is there any conditional convergence of economic growth in Aceh province, when depending each other in counties spatial is calculated in times period of this research study?

3) Is there any spatial transformation of counties indicates positive location influenced to economic growth in Aceh?.

\section{Research Objectives}

Some specific objectives which are reached in this research are to know and analyses:

1) Statistically difference, before and after spatial transformation of counties to economic growth in Aceh province

2) Conditional convergence of economic growth in Aceh province, when depending each other in counties spatial is calculated in times period of this research study

3) Spatial transformation of counties indicates positive location influenced to economic growth in Aceh.

\section{Theoretical Review}

A region develop and growth will impact on concentration of population and economic activities with varies speed. Depending on spatial scale of economic resources (World Bank, 2009). It is same way to study of Sardavar (2011), Tian, Wang and Chen (2010), Debarsy (2006), Sodik (2006), Mandariaga, Ollivaud and Montout (2006), Dayanandan and Ralhan (2005), Marquez and Yrigoyen (2004). Economic growth of a region is not depending overall on their revenue, level savings, human phisical capital, and technology, but also influnced by sorrounding region or spatial spillover effect. Commonly interaction between region exibite relate their resources. Therefore relationship between regions to be important study. In economic activities, spatial effect/existance of location to be important factor. Von Thunen starting study theory of location in 19th century in Germany with Bid Rent Theories. According to Von Thune theory, selection of land is based on the ability to pay bid rent that differ to price of land, where the use of land depen on bid rent rate and relative accessibility of economic activities (Von Thune in Sjafrijal, 2008).

World Bank (2009) provide reports of world development, there are 3 spatial dimension which concern to development process and economic growth of region, as follows :

1. The density, economic aggregate per unit land or density of geographic activities. It could be measured by a value added of per square kilometer land or Gross Domestic product (GDP).

2. The Distance, define as accessibility of goods, services, labor, capital, information and idea across space. Easibility of capital flows, labor moved, the goods being transported, and the services provided into two location.

3. Distribution of space function, solution for restriction of economic interaction each region to manage flows of goods and production factors which be able distribute overall region in order benefit of economic interaction could be affected.

There are three (3) reasons existance of conditional convergence of economic growth (Römer in Sardadvar, 2011):

1) Convergence predict a balanced economic growth path (balance growth), if there are two regions/areas which had relatively diverse of economic growth, in the time point will be meet at the same balanced growth. Therefore, the poor economies region tends grow faster to be same growth rate rich ecomomies.

2) Neoclassical production function assumes the marginal product of physical capital will decrease when the 
number of labor per unit increases. That means at condition of ceteris paribus, the return on physical capital rate is higher atlow economy. Therefore the output increase from physical capital function will leads to convergence.

3) A part of economic output is also a technology function, where the changing of knowledge support improvement of technology impact on economic growth fastly and stimulate to speed of convergence.

According to Barro and Martin (2004), two testing based on theory of convergence, fistly absolute convergence, which involves testing the hypothesis that poor economiestend to grow faster per capita than rich ones without conditioning on anycharacteristics of economies. Secondly conditional convergence, by allowing for heterogeneity across economies andtesting the hypothesis that an economy grows faster the further it is from its ownsteady state.

\section{Methods}

Techniques of data collection in this study using two main techniques, namely the study of documents and observation. Data that used in this research is combined data between cross-section data (spatial units) and time series data. The results are analyzed in quantitative research, starting by examining all the data available from various sources, from documents and observations that have been written in the field notes, personal documents, official documents, images, photographs, and so on, through data analysis procedure that is data reduction, unitization of data, categorization of data, and interpretation of data. In other words, Analysis model in this research is using a model set of research data analysis, which is show relation between observed and measured concepts to answer research objectives and support research hypothesis in this dissertation. Data analysis which used are descriptive analysis, continue with Spatial Durbin Model (SDM) approach which is show significance pattern of the perfomance interpendence. Exploratory Spatial Data Analysis (ESDA) by using Statistical Analysis System (SAS) and Minitab Software

\section{Results}

Regression for complete model was built in equation (4)with 12 parameter are shown below:

Table 2. Regression test results of analysis of Econometrics spatial model of economic growth in the Province of Aceh, after the transformation of spatial, 2006 until 2010.

\begin{tabular}{|c|c|c|c|c|c|c|c|c|c|c|}
\hline \multirow{2}{*}{$\begin{array}{l}\text { Para- } \\
\text { meter }\end{array}$} & \multicolumn{2}{|l|}{2006} & \multicolumn{2}{|l|}{2007} & \multicolumn{2}{|l|}{2008} & \multirow{2}{*}{$\begin{array}{l}2009 \\
\text { Coef. }\end{array}$} & \multicolumn{3}{|c|}{2010} \\
\hline & Coef. & Wald & Coef. & Wald & Coef. & Wald & & Wald & Coef. & Wald \\
\hline & $-0,068$ & 0,489 & $-0,9933$ & $38,525^{*}$ & $-0,017$ & 0,013 & $-0,002$ & 0,0002 & $-0,389$ & $5,43 *$ \\
\hline & $-0,127$ & $116,037 *$ & $-0,120$ & $171,989^{*}$ & $-0,124$ & $79,878^{*}$ & $-0,144$ & $211,717^{*}$ & $-0,147$ & $289,84^{*}$ \\
\hline & 0,001 & 0,118 & $-0,003$ & 0,8411 & $-0,002$ & 0,175 & $-0,002$ & 0,501 & 0,001 & 0,055 \\
\hline & $-0,106$ & $130,005^{*}$ & $-0,088$ & $80,291 *$ & $-0,109$ & $35,765^{*}$ & $-0,124$ & $105,670^{*}$ & $-0,132$ & $138,136^{*}$ \\
\hline & 0,111 & $143,335^{*}$ & 0,117 & $68,392 *$ & 0,110 & $26,265^{*}$ & 0,129 & $73,689 *$ & 0,144 & $99,273 *$ \\
\hline & $-0,007$ & $6,239 *$ & $-0,008$ & $9,484 *$ & 0,003 & 1,088 & $-0,002$ & 0,631 & $-0,009$ & $12,076^{*}$ \\
\hline & 0,103 & $13,229 *$ & $-0,123$ & $20,415^{*}$ & 0,067 & $4,309 *$ & 0,098 & $16,356^{*}$ & 0,054 & $3,268 * *$ \\
\hline & 0,002 & 0,061 & 0,001 & 0,028 & $-0,004$ & 0,195 & $-0,010$ & 1,291 & $-0,006$ & 1,117 \\
\hline & 0,077 & $11,492 *$ & $-0,129$ & $28,830 *$ & 0,052 & $1,689 * * *$ & 0,060 & $5,490 *$ & 0,006 & 0,034 \\
\hline & $-0,081$ & $11,593^{*}$ & 0,177 & $28,182 *$ & $-0,054$ & 1,366 & $-0,065$ & $4,473^{*}$ & 0,006 & 0,025 \\
\hline & 0,006 & $1,165^{*}$ & 0,021 & $9,865 *$ & 0,004 & 0,482 & 0,013 & $4,489 *$ & 0,005 & 1,085 \\
\hline & 0,522 & $8,117 *$ & 1,000 & $30,715^{*}$ & 0,466 & $5,597 *$ & 0,631 & $17,439 *$ & 0,309 & $2,17 * * *$ \\
\hline Rsq & 0.884 & & 0.902 & & 0.915 & & 0.959 & & 0.974 & \\
\hline
\end{tabular}

Note: $*$ ) significantat the $5 \%$ level, $* *)$ at the $10 \%$ level, and $* * *)$ at the $20 \%$ level.

Regression parameter test results of spatial Econometrics analysis model in this research, indicate that "there is a significant conditional convergence of economic growth in the province of Aceh when the spatial interdependence of districts/counties accounted for in the period of this research study".This is demonstrated by empirical evidence, parameter of a conditional convergence $(-\beta)$ which significantly to economic growth in the province of Aceh and the spatial coefficient correlation of lag positive/significant, after the transformation of spatial (from 2001 until 2010). That mean, the interpretation of the results of research using the model of spatial Econometrics analysis shows, there is a fairly close relatedness of the district/counties in the spatial aspects of the economic growth in the Pprovince of Aceh. An increase in economic growth influenced by surrounding district/counties (neighboring). It could be a positive influence on the development of regional economic growth in districts/counties in the surrounding area in improving economic growth in the Province of Aceh.

\section{CONCLUSIONS AND SUGGESTIONS}

\section{Conclusions}

1) Economic growth in the province of Aceh tend to be influenced by location and linkages are quite closely, from the nearest districts/counties (neighboring) towards economic growth in the Province of Aceh. Increased economic growth area of districts/counties nearby, It can be a positive influence to increased economic growth in the region surrounding districts/ counties in the Province of Aceh. 
2) In the long term, the economy of the districts/ counties in Aceh province that previously had relatively low economic growth, will be able to catch-up growth in its economy in the levels (the size of) their per capita income being more rapidly than in other districts/counties that previously had been growing more rapidly, in improved economic growth in the Province of Aceh, Indonesia.

\section{Suggestions}

1) Capital resources (capital investment) are important close to main priority, to manage natural resources and improve the quality of science and technology in Aceh.

2) The existence of human resources, with a high amount of labor force in Aceh, must be accompanied by the availability of jobs in order to increase the marginal product of physical capital (Gross Regional Domestic Product per capita).

3) The use of technology, through the application of new technologies in terms of differences in productivity engineering will be able to produce value added for the output of the economy of the districts/counties in the Province of Aceh.

4) The ability of communities and employers in the districts/counties to participate in the local, national and global market as well as will bring out increasing the economy of the districts/counties inthe Province of Aceh.

\section{REFERENCES}

Anselin, Luc. (1988), Spatial Econometrics: Methods and Models. Kluwer Academic Publishers. Dordrecht Anselin, Luc. (2005), Exploring Spatial Data With GeoDa : A workbook. Champaign- Urbana: University of Illinois.

BPS. (2011), Gross Regional Domestic Product (1990 s/d 2010).The Provinsi of Aceh.

Badinger, H., Muller, W. and Tondl, G. (2002), Regional Convergence in The European Union (1985-1999) A Spatial Dynamic Panel Analysis, Journal of Economic Literature, C23, O00, R11.

Barro, Robert J and Xavier, Sala-i-Martin. (2004), Economic Growth, 2nd edn. London: MIT Press Cambridge.

Debarsy, N. and Erthur, C. (2006). The European Enlargement process and regional convergence revisited: Spatial effects still matter, Centre de Recherches sur l'Economie Wallonne (CREW) Faculté des sciences économiques socials.

Elhorst, J. Paul. (2011), Spatial Panel Model, Journal of Economic Literature, C21, C23, C51

LeSage, J and Pace RK. (2009), The Theory and Practice of Spatial Econometrics. New York: University Toledo. Mandariaga, Montout, dan Ollivaud. (2005). Regional Convergence and Agglomeration in Argentina : A Spatial Panel Data Approach. Sorbonne, Universite Paris.

MarquezJ.M.M. and Yrigoyen C.C. (2004). Urban Growth and Territorial dynamics in Spain : A Spatial Econometric Analysis, Regional Science Association International and Regional Economic Application Laboratory Seminar at the University of Illinois at Urbana-Campaign in Agustus 2004.

Quah, D. (1993), Empirical Cross-section Dynamics in Economic Growth, European Economic Review, 37, pp. 426-434.

Ralhan, M. dan A. Dayanandan. (2005). Convergen of Income Among Provinces in Canada-An Application of GMM estimation. Econometric Working Paper EWP 0502 : 13-21

Sardadvar, S. (2011), Economic Growth in the Regions of Europe : Theory and Empirical Evidence From a Spatial Growth Model. Berlin: Springer-Verlag.

Sodik, Jamzani. (2006). Regional economic growth: case study analysis of the Konvegensi Between provinces in Indonesia, Journal of Development Economics Vol. 11 No. 1, Arpil 2006 page 21-32.

Sjahrizal. Prof. (2008), Regional economies: theory and applications. Padang: Baduose Media.

Tian, L. Wang, H dan Chen, Y. (2010), Spatial Externalities in China Regional Economic Growth, China Economic Review, Vol. XXX P. 1-12.

Word Bank. (2009), Reorganized The Economic Geography.Jakarta : Salemba Empat. 
The IISTE is a pioneer in the Open-Access hosting service and academic event management. The aim of the firm is Accelerating Global Knowledge Sharing.

More information about the firm can be found on the homepage:

http://www.iiste.org

\section{CALL FOR JOURNAL PAPERS}

There are more than 30 peer-reviewed academic journals hosted under the hosting platform.

Prospective authors of journals can find the submission instruction on the following page: http://www.iiste.org/journals/ All the journals articles are available online to the readers all over the world without financial, legal, or technical barriers other than those inseparable from gaining access to the internet itself. Paper version of the journals is also available upon request of readers and authors.

\section{MORE RESOURCES}

Book publication information: http://www.iiste.org/book/

\section{IISTE Knowledge Sharing Partners}

EBSCO, Index Copernicus, Ulrich's Periodicals Directory, JournalTOCS, PKP Open Archives Harvester, Bielefeld Academic Search Engine, Elektronische Zeitschriftenbibliothek EZB, Open J-Gate, OCLC WorldCat, Universe Digtial Library, NewJour, Google Scholar

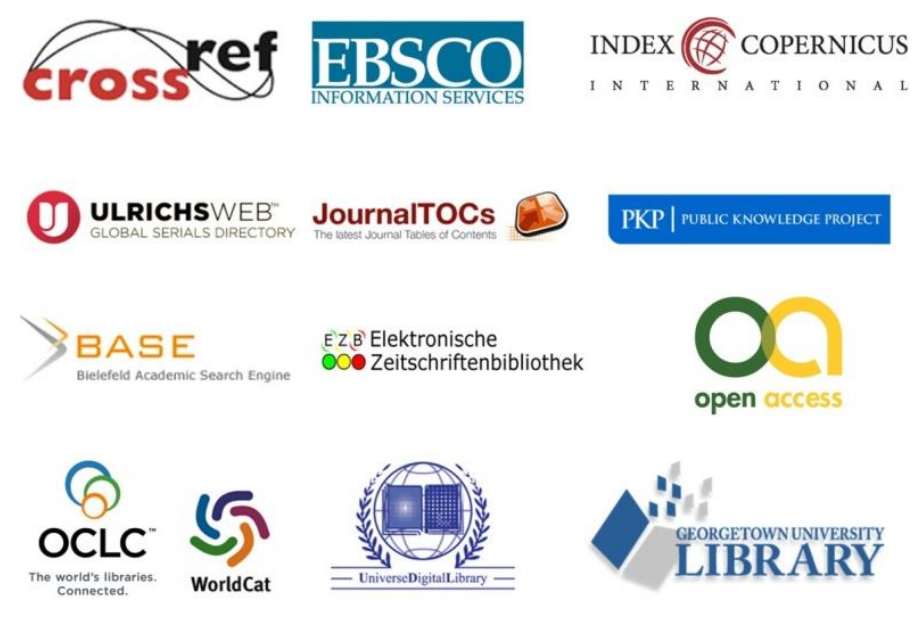

